\title{
BANK SPECIFIC DETERMINANTS OF EU BANKS PROFITABILITY AFTER 2007 FINANCIAL CRISIS
}

\author{
Roberto Ercegovac * \\ Ivica Klinac ** \\ Ivica Zdrilić ${ }^{* * *}$
}

Received: 13. 1.2020

Preliminary communication

Accepted: 30. 5. 2020

UDC 336.71:33.054.22 (4-6EU)

DOI https://doi.org/10.30924/mjcmi.25.1.5

\begin{abstract}
The basic purpose of the paper is to research determinants on profitability indicators of the banks in the European Union. Analysed bank profitability indicators considered as a standard are: the return on total bank assets (ROA) and return on total bank equity (ROE). The research model of bank profitability determinants is developed by analysing the systemically important, quoted banks in the European Union, in the 2007-2019 period, by using an adequate panel data analysis technique. The empirical evidence is in line with the initial assumptions: the efficiency of the banking firm, measured by the cost to income ratio and the non-performing loans ratio, has a significant influence on bank profitability, both on ROA and ROE. In the postcrisis period, banking firms ask for efficient cost management in achieving performance objectives. Additional important empirical results of research are the absence of impact of assets size and regulatory capital ratio on profitability indicators. The most important contribution of the paper is related to the sample definition, variable selection and explanatory power of the presented model in explaining global banking tendencies.
\end{abstract}

Key words: bank profitability, regulatory requirements, dynamic panel models, systemically important banks, European banking sector

\section{INTRODUCTION}

The most important changes in the regulatory and business environment in the European Union after the global financial crisis have been implemented in the banking system. Beside the direct regulatory costs, banks are faced with an increase of competition of non-banking companies and the expenses of new technologies implemented in the transformation of traditional banking products and services. Due to new market conditions, banks are under the challenge of preserving desirable business performance indicators to continue the business activity, and to ensure the resilience and stability of the banking firms. The base indicators of bank performance

\footnotetext{
* Roberto Ercegovac, PhD, OTP Bank Croatia d.d./ University of Split, Faculty of Economics, Split, Croatia, Cvite Fiskovića 5, 21000 Split, Croatia, Telephone: +385 21304 801, E-mail: roberto.ercegovac@efst.hr

** Ivica Klinac, PhD, University of Zadar, Department of Economics, Zadar, Croatia Splitska ulica 1, 23000 Zadar, Croatia, Telephone: +385997368 424, E-mail: iklinac1@unizd.hr

${ }^{* * *}$ Ivica Zdrilić, PhD, University of Zadar, Department of Economics, Zadar, Croatia, Splitska ulica 1, 23000 Zadar, Croatia, Telephone: +385 23400 408, E-mail: izdrilic@unizd.hr
} 


\section{Journal of Contemporary Management Issues}

measures are return on total bank assets (ROA) and return on total bank equity (ROE). As an indicator of bank profitability, some authors favour the ROA over the ROE (Pasiouras and Kosmidou, 2007), (Sufian, 2012). However, the indicator of the return on total bank equity remains a standard measure of the profitability of the banking firm due to its appreciation of the leverage effect, explained in detail in the study by Dietrich and Wanzenried (2011). The regulatory framework of continuous monitoring of assets quality and normative leverage ratio is explicit driver of ROE, which should furthermore give comfort to bank regulators and depositors in control of abusing the leverage effects in increasing ROE (Klaassen and van Eeghen, 2015).

The volatility of bank profitability indicators is directly linked with the macroeconomic environment in which banks operate (Athanasoglou et al., 2008). Dietrich and Wanzenried (2011) analysed the sensitivity of the banking sector's profitability indicators to macroeconomic disturbances, which stem from a reduction in investment potential, a decrease in credit demand and a deterioration in loan assets quality. The indicators of the profitability of the banking firm also depend on the banking system attributes, its depth, and the width of services, competitiveness and concentration, and the very structure of bank ownership (Košak and Čok, 2008). Besides, the most important determinants of bank's overall performance measures in the homogeneous business environment are internal bank specifics.

Due to the share of loan assets in banking firms, bank has the most exposure to the credit risk (Saeed and Zahid, 2016). Quality management of credit risks directly affects the bank's profitability indicators, as it reduces the provision of bad debt assets with a direct impact on the cost of risk (Jeitschko and Jeung, 2005). The health of the bank assets is measured by the non-performing loan to total bank assets ratio (NPL). The NPL is the indicator of credit risk management quality as well as the bank policy in risk and return trade off and performance measure improvement (Simanjuntak and Pangestuti, 2017). In addition to the efficient management of credit risks within the scope of the loan, the bank's performance is also affected by the assets risk profile and the structure of the bank capital. Some authors have found that a higher regulatory capital ratio reduces the risk and increases the banking firm profitability and efficiency (Bitar et al., 2018). Banks increased the regulatory capital ratio, because of regulatory changes and requirements for additional capital, as well as the higher ratio of liquidity and risk free assets (ECB, 2017).

Other studies emphasize that the profitability of the banking sector is related to the cost function, while cost input factors, due to technological progress and bank competition, are decreasing since the last crisis (Spierdijk et al., 2017). Boucinha et al. (2013) analysed the effects of production and organization changes in moving the cost frontier function in Portuguese banking system downwards. The evaluation and management of profitability are critically important in bank management, in order to achieve business performance objectives (Casu et al., 2004). Burger and Moormann (2008) conclude that the most popular indicator of productivity in the banking sector is the cost to income ratio (CIR). High CIR shows higher administrative costs to operating income and is an 
equivalent of low profitability of a banking firm, with negative income on profitability indicators to be expected.

ROE and ROA are the most commonly used indicators of bank profitability. This paper will analyse the impact of three main bank profitability determinants during the post crisis period: the ratio of non-performing loans, the regulatory capital ratio and the cost to income ratio. Comparison with other papers will provide comparative analysis of selected indicators in the post crisis period on individual bank level and homogeneous European Union banking system as a whole. The main research hypothesis is that impact of CIR is the most significant, due to the regulatory adjustment of European banks to new capital requirements and risk management standards (Klinac and Ercegovac, 2018), which applies specifically to systemically important banks (Ercegovac and Buljan, 2018). The hypothesis is tested by data panel model on the sample of 22 European publicly quoted banks.

\section{LITERATURE REVIEW}

Many researchers have been preoccupied with bank profitability determinants. In early studies, the risk management efficiency, bank concentration, interest rates and government ownership had shown the strong impact on bank profitability (Short, 1979; Molyneux and Thorton, 1992). Modern studies include more variables in bank profitability determinants. Most research papers are country-specific: China (Heffernan and Fu, 2008), Indonesia, (Mala, 2017), (Jumono et al., 2016), Croatia (Kundid et al., 2008), Czech, Hungary and Romania (Andries and Cocris, 2010) and many others. Other studies analyse the bank profitability by a group of countries. Goddard et al. (2004) found that strong capitalized banks with higher ratio of liquid assets are less profitable, with no effect of bank size. Other researchers found that bank profitability is correlated with bank concentration and level of inflation, but GDP per capital volatility does not have a significant impact (Athanasoglou et al., 2006). Estimation results of Staikouras and Wood (2004) emphasise the macroeconomic impact on profitability, even stronger than the management efficiency. Petria et al. (2015) found that bank profitability is directly linked with liquidity and credit risk management, efficiency, market concentration, economic growth and portfolio diversification. To conclude, in comparison with other researches, this paper will include systemically important EU banks that are market leaders and will define the tendencies of banking business.

\section{RESEARCH SAMPLE AND MODEL VARIABLES}

Based on the public quotation criterion, the research sample was formed using the Bloomberg database. Portfolio of 22 banking groups operating from 2007 to 2019 with the corresponding balance sheet data and specific business indicators was selected (see Table 1). Impact of bank mergers, acquisitions and cross-border takeovers on dependent variables during the observed period had been avoided and not considered relevant in this research problem, which makes the research model less complex. Finally, the analysed banking groups are undoubtedly market makers on the single EU banking market. They make systemically important business activities in the same economic area 
Journal of Contemporary Management Issues

Table 1. Sample bank data average (2007 - 2019)

\begin{tabular}{|c|c|c|c|c|c|c|c|}
\hline Bank name & Country & $\begin{array}{l}\text { Ln } \\
\text { Assets }\end{array}$ & $\begin{array}{l}\text { NPA_Ratio } \\
\text { (\%) }\end{array}$ & $\begin{array}{l}\text { TCaP } \\
\text { Ratio (\%) }\end{array}$ & $\begin{array}{l}\text { Eff_Ratio } \\
(\%)\end{array}$ & $\begin{array}{l}\text { ROA } \\
(\%)\end{array}$ & $\begin{array}{l}\text { ROE } \\
(\%)\end{array}$ \\
\hline ABN Amro Group NV & Netherland & 12,87 & 1,71 & 20,74 & 65,05 & 0,35 & 7,67 \\
\hline Banco Bilbao Vizcaya & Spain & 13,34 & 2,90 & 14,26 & 54,11 & 0,61 & 9,41 \\
\hline Banco Santander, SA & Spain & 14,03 & 2,43 & 13,89 & 55,40 & 0,55 & 8,10 \\
\hline Barclays, PLC & UK & 14,28 & 0,98 & 17,83 & 62,01 & 0,18 & 4,71 \\
\hline BNP Paribas, SA & France & 14,50 & 1,81 & 13,68 & 65,31 & 0,31 & 6,93 \\
\hline CaixaBank, SA & Spain & 12,74 & 5,74 & 14,35 & 69,25 & 0,31 & 4,55 \\
\hline Commerzbank, AG & Germany & 13,27 & 1,99 & 15,87 & 74,39 & 0,06 & 1,05 \\
\hline Crédit Agricole, SA & France & 14,28 & 1,02 & 15,04 & 65,97 & 0,12 & 2,96 \\
\hline Credit Suisse Group AG & Switzerland & 13,53 & 0,22 & 19,43 & 78,01 & 0,19 & 4,26 \\
\hline Danske Bank, A/S & Denmark & 13,04 & 1,93 & 19,01 & 57,32 & 0,27 & 6,41 \\
\hline Deutsche Bank, AG & Germany & 14,35 & 0,47 & 16,17 & 81,41 & 0,01 & 3,01 \\
\hline Erste Group Bank, AG & Austria & 12,26 & 5,43 & 15,41 & 61,47 & 0,32 & 4,26 \\
\hline HSBC Holdings, PLC & UK & 14,51 & 1,16 & 16,23 & 56,72 & 0,46 & 6,95 \\
\hline Intesa Sanpaolo, SpA & Italy & 13,43 & 6,37 & 14,72 & 57,84 & 0,29 & 3,67 \\
\hline KBC Group, NV & Belgium & 12,57 & 2,86 & 17,64 & 57,88 & 0,56 & 8,72 \\
\hline $\begin{array}{l}\text { Lloyds Banking Group, } \\
\text { PLC }\end{array}$ & UK & 13,74 & 2,60 & 18,45 & 65,86 & 0,21 & 4,81 \\
\hline Nordea Bank, AB & Sweden & 13,26 & 0,83 & 17,72 & 51,95 & 0,51 & 10,75 \\
\hline $\begin{array}{l}\text { Royal Bank of Scotland, } \\
\text { PLC }\end{array}$ & UK & 14,13 & 1,92 & 17,63 & 69,99 & $-0,19$ & $-4,53$ \\
\hline Société Générale & France & 14,02 & 1,69 & 14,16 & 68,72 & 0,21 & 4,56 \\
\hline Swedbank, AB & Sweden & 12,23 & 0,75 & 21,80 & 46,05 & 0,65 & 11,72 \\
\hline UBS Group, AG & Switzerland & 13,79 & 0,23 & 22,30 & 80,37 & 0,28 & 5,22 \\
\hline UniCredit, SpA & Italy & 13,71 & 6,61 & 13,78 & 68,48 & 0,05 & 0,50 \\
\hline
\end{tabular}

Source: Bloomberg (2020).

Following the research by Klinac and Ercegovac (2018), where authors analysed the adjustment of banks' business activities towards the new regulatory requests, as well as Klinac et al. (2019), where authors analyzed restoring of the investment public confidence towards the self-financing capacity of the banking industry as a whole, using the same methodology, in this study, the influence of specific banking determinants on profitability indicators are examined. The authors are also questioning, whether the credit risk and efficiency management lead to better outcome performance. The dependent variables of the research is the sustainable profitability performance, usually presented by the return on assets (ROA), or the return on banks' capital (ROE). The sustainable profitability performance is in direct relation with the long run risk management and efficiency ratio, due to the cost intensive adjustment of banks to the new business and regulatory environment. Thus, the following independent variables related to the sustainable profitability have been selected: 
- $\quad$ Ln_Assets - the size of a banking firm. From the dynamical point of view the indicator reflects the chosen overall business and risk operation model of an individual banking group,

- NPA_Ratio - a ratio that gives us information about the level of the individual bank's credit risk and the loan portfolio quality of the same. In the long run, it dynamically represents the chosen risk management model of the particular banking firm,

- TCaP_Ratio - an analytical ratio that represents the level of regulatory capital in relation to the risk weighted assets (RWA). Definition and content are the sole responsibility of the regulator and are intended to cover potential losses incurred by a bank firm's poor performance,

- Eff_Ratio - a ratio that gives us information about the bank's overheads as the percentage of its revenue. It dynamically allows us to assess the ability of the managing structures to turn banking firm's assets into operating revenues through corporate governance.

Table 2. Variable descriptions and expected influence

\begin{tabular}{lll}
\hline Label & Description & Expected influence \\
\hline ROA & Return on total bank assets & Dependent variable \\
ROE & Return on total bank equity & Dependent variable \\
Ln_Assets & Natural logarithm of the total assets & + \\
NPA_Ratio & Non-performing assets & - \\
TCaP_Ratio & Total regulatory capital & + \\
Eff_Ratio & Cost/Income ratio & - \\
\hline
\end{tabular}

Source: Authors

\section{ECONOMETRIC APPROACH AND EMPIRICAL MODEL}

From the subjected sample of this research, a balanced panel data set has been created. According to Cameron and Trivedi (2005), panel data are repeated observations on the same cross-sections, typically of individuals or firms in microeconomics applications, observed for several periods. Verbeek (2004) points out that panel data allow identification of certain parameters or questions, without limiting the assumptions, comparing it to time series or cross-sectional assemblies. Wooldridge (2002) highlighted the heterogeneity control at individual level and the assumed difference between the observed units during the panel data analysis, whereas models without that kind of feature may produce bias estimation. Finally, the panel model enables high information effect from reduced observation data source, with reduced multicollinearity issues (Škrabić Perić, 2012). The determinants of the sustainable profitability have been analysed by a dynamic panel regression model, using the GMM estimator. Namely, research variables are of a dynamic nature and due to absence of autocorrelation, using the static panel models is not suitable for this kind of estimation. Moreover, the dynamic panel models solve effectively the problem of endogeneity and manage the issue of heteroscedasticity and autocorrelation of residuals (Pivac et al., 2017). Therefore, for the purpose of this study, the basic model is as follows: 


$$
\begin{gathered}
y_{i, t}=\mu+\gamma \cdot y_{i, t-1}+\beta_{1} \cdot x_{i, t}+\beta_{2} \cdot x_{i, t}+\cdots+\beta_{k} \cdot x_{i, t k}+\alpha_{i}+\varepsilon_{i, t}, \\
i=1, \ldots N, t=1, \ldots T .
\end{gathered}
$$

where $\mathrm{i}$ is the unit, $\mathrm{t}$ the time, $\mu$ the constant, $\gamma$ the parameters besides the dependent variables with a lag, $\beta 1, \beta 2, \ldots, \beta \mathrm{k}$ the exogenous variables parameters, $x i, t$ the independent variables, $\alpha \mathrm{i}$ a specific error for a i-th bank, and $\varepsilon i, t$ the error of relation of the i-th bank.

In order to meet the Arellano-Bond's estimator requirement, the number of banks is larger than the number of periods. Therefore, the performances of the GMM evaluator system have not been questioned while the dependent variable in one step was used as an instrument. Namely, based on the additional panel model analysis, the dynamic panel with a GMM estimator in one step is used with the robust standard errors. Finally, the validity of the models is estimated based on the autocorrelation test of the first differences of the second order residuals. Because of the robust standard errors features, the Sargan test cannot be used.

\section{RESEARCH RESULTS AND DISCUSSION}

The descriptive statistics of all observed variables are presented in Table 3. Moreover, based on the average value for all banking groups for each of the observed years, the dynamic features of the dependent variable are presented in Table 4.

Table 3. Descriptive statistics

\begin{tabular}{llllll}
\hline Variable & Obs & Mean & Std. Dev. & Min & Max \\
\hline \multicolumn{5}{c}{ Banks business indicators } \\
\hline ROA & 274 & 0.2876 & 0.3894 & -1.6908 & 1.2654 \\
ROE & 273 & 5.2753 & 7.2632 & -35.4545 & 28.4528 \\
Ln_Assets & 281 & 13.5523 & 0.7050 & 12.0155 & 14.7353 \\
NPA_Ratio & 271 & 2.3422 & 2.2104 & 0.1082 & 9.9594 \\
TCaP_Ratio & 272 & 16.7578 & 4.0340 & 8.6000 & 31.8000 \\
Eff_Ratio & 274 & 63.9639 & 11.4413 & 31.0987 & 99.2169 \\
\hline
\end{tabular}

Source: Authors

Table 4. Average values of ROA and ROE

\begin{tabular}{llllllllllllll}
\hline Year & 2007 & 2008 & 2009 & 2010 & 2011 & 2012 & 2013 & 2014 & 2015 & 2016 & 2017 & 2018 & 2019 \\
\hline ROA & 0.6 & 0.3 & 0.2 & 0.3 & 0.1 & 0.1 & 0.1 & 0.2 & 0.3 & 0.3 & 0.4 & 0.5 & 0.4 \\
ROE & 14.4 & 5.4 & 3.0 & 6.1 & 2.1 & 2.0 & 1.7 & 3.8 & 5.1 & 5.2 & 6.5 & 7.6 & 7.0 \\
\hline
\end{tabular}

Source: Authors

It could be noticed that, after the expiration of the expansionary growth trends of bank assets and overall business performance, a drastic fall in the profitability indicators occurred in all observed banking groups after 2007/2008 global financial crises (see Figure 1). 


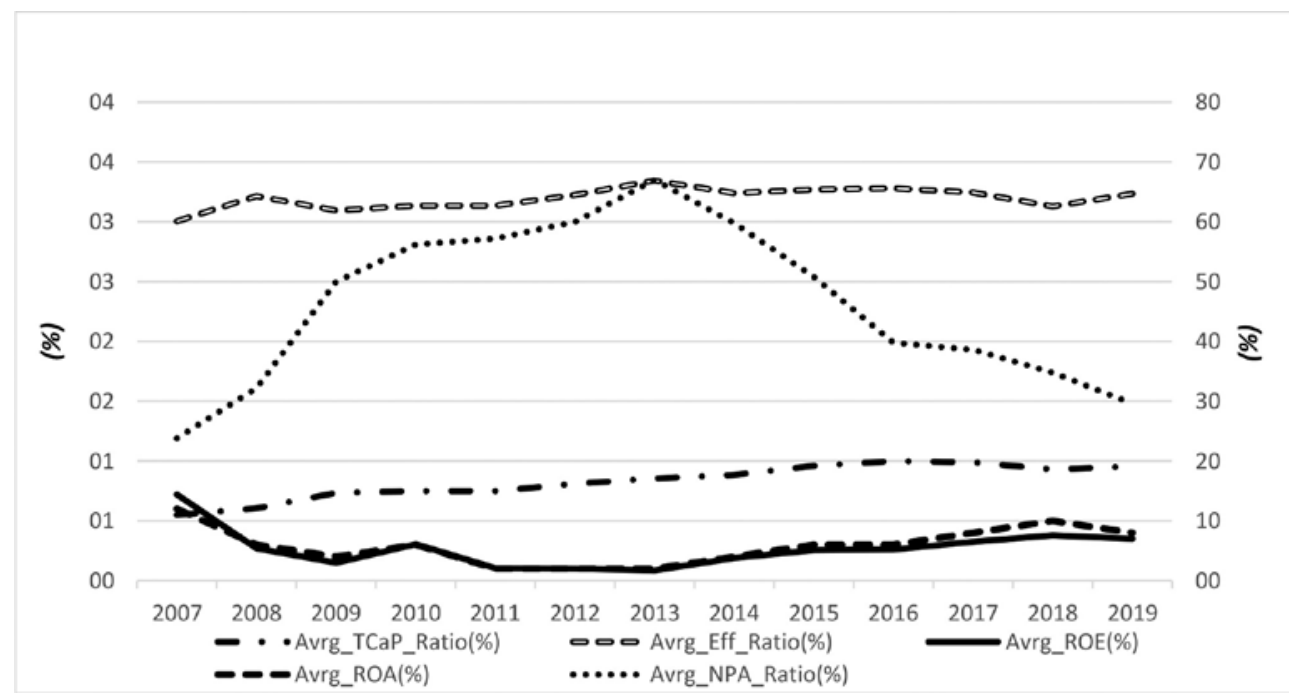

Figure 1. The dynamics of the average value of bank sustainable profitability performance

Sources: Bloomberg and authors (2020).

Notes: Avrg_TCap_Ratio - (right scale); Avrg_Eff_Ratio - (right scale); Avrg_ROE - (right scale); Avrg_ROA - (left scale); Avrg_NPA_Ratio - (left scale).

Even though slight recovery occurred afterwards, obviously it was not based on the real fundamental value, especially when the sovereign crisis peaked between 2010 and 2012. Further movement of the profitability indicators was marked by the massive reduction of non-performing assets and especially in the reduction of credit exposure toward SME and risky project portfolio (Klinac and Ercegovac, 2018), helping to improve financial stability, but at the same time can deepen undesirable economic stagnation (Raluca, 2020). Finally, overall business performances will certainly continue to be driven by the further implementation of Basel Standard regulatory principles as well as the expected positive effects of narrowing the pre-crisis economies of scale by reducing business segments oriented mostly to operations in the capital markets.

In order to estimate the model, a check whether there is a potential multicollinearity problem between the selected variables is required (Pivac et al., 2017). Although there is no adequate test, detecting the multicollinearity in panel models, the most empirical studies use coefficients between independents not higher than 0.5 to discover the multicollinearity related issues. The correlation matrix for the subject research is shown in Table 5, indicating there are no pairs of variables causing the multicollinearity problem. Due to the expected strong connection between the dependent variables exceeding the value of 0.9 , two separate models were constructed, according to the research assumptions. 
Journal of Contemporary Management Issues

Table 5. Correlation matrix

\begin{tabular}{lllllll}
\hline & ROA & ROE & Ln_Assets & NPA_Ratio & TCaP_Ratio & Eff_Ratio \\
\hline ROA & 1 & & & & & \\
ROE & 0.9436 & & & & & \\
& $(0.0000)$ & 1 & & & & \\
Ln_Assets & -0.2515 & -0.2193 & & & & \\
& $(0.0000)$ & $(0.0003)$ & 1 & & & \\
NPA_Ratio & -0.2193 & -0.2763 & -0.2680 & 1 & & \\
& $(0.0003)$ & $(0.0000)$ & $(0.0000)$ & & & \\
TCaP_Ratio & 0.0945 & 0.0583 & -0.2031 & -0.2876 & 1 & \\
& $(0.1214)$ & $(0.3396)$ & $(0.0008)$ & $(0.0000)$ & & \\
Eff_Ratio & -0.4862 & -0.4874 & 0.2872 & -0.0853 & 0.0072 & 1 \\
& $(0.0000)$ & $(0.0000)$ & $(0.0000)$ & $(0.1624)$ & $(0.9062)$ & \\
\hline
\end{tabular}

Source: Authors

Finally, in order to test stationarity issues of the research sample all variables are tested for the existence of unit root in panel data series using Dickey - Fuller test (Table 6). The results clearly show that all variables in the analysis are first-difference variables. For both dependent and explanatory variables, the null hypothesis that a unit root is present in data series was rejected at $1 \%$ statistical significance.

Table 6. Dickey-Fuller test of the stationarity

\begin{tabular}{lllllll}
\hline & ROA & ROE & Ln_Assets & NPA_Ratio & TCaP_Ratio & Eff_Ratio \\
\hline t-stat & -19.5686 & -18.9991 & -13.4374 & -10.4166 & -15.7265 & -20.6025 \\
p-value & 0.0000 & 0.0000 & 0.0000 & 0.0000 & 0.0000 & 0.0000 \\
\hline
\end{tabular}

Source: Authors

To test our research hypothesis, regard- regression models of panel analysis can be ing sustainable profitability indicators, written as follows:

$$
\begin{aligned}
\Delta \boldsymbol{R O A}_{i, t}=\mu+ & \gamma \cdot \Delta \text { ROA }_{i, t-1}+\beta_{1} \cdot \Delta N P A_{-} \text {Ratio }_{i, t}+\beta_{2} \cdot \Delta \text { TCap_Ratio }_{i, t}+\beta_{3} \cdot \Delta \text { Eff_Ratio }_{i, t}+\beta_{4} \\
& \cdot \Delta \text { Ln_Assets }_{i, t}+\alpha_{i}+\varepsilon_{i, t} \\
& i=1, \ldots N, t=1, \ldots T . \\
\Delta \boldsymbol{R O E}_{i, t}=\mu+ & \gamma \cdot \Delta \text { ROE }_{i, t-1}+\beta_{1} \cdot \Delta N P A_{-} \text {Ratio }_{i, t}+\beta_{2} \cdot \Delta \text { TCap_Ratio }_{i, t}+\beta_{3} \cdot \Delta E f f_{-} \text {Ratio }_{i, t}+\beta_{4} \\
& \cdot \Delta \text { Ln_Assets }_{i, t}+\alpha_{i}+\varepsilon_{i, t} \\
& i=1, \ldots N, t=1, \ldots T .
\end{aligned}
$$

The obtained empirical results are presented in Table 7.

Table 7. The panel analysis influence on profitability measures of European banks

\begin{tabular}{lll}
\hline Dependent variable & $\Delta$ ROAi,t & $\Delta$ ROEi,t \\
\hline Lag_1 & $0.1590^{* *}$ & $0.2000^{* * *}$ \\
& $(0.0818)$ & $(0.0770)$ \\
\hline
\end{tabular}




\begin{tabular}{lll}
\hline$\Delta \mathrm{NPA}$ Ratioi,t & $-0.0981^{* * *}$ & $-1.6734^{* *}$ \\
$(0.0384)$ & $(0.7557)$ \\
\hline$\Delta \mathrm{TCaP}$ Ratioi,t & 0.0032 & 0.0267 \\
& $(0.0115)$ & $(0.1991)$ \\
\hline \multirow{2}{*}{ Eff_Ratioi,t } & $-0.0073^{* * *}$ & $-0.1626^{* * *}$ \\
& $(0.0027)$ & $(0.0587)$ \\
\hline \multirow{2}{*}{$\Delta$ Ln_Assetsi,t } & 0.4041 & 4.1817 \\
\hline & $(0.4298)$ & $(7.6958)$ \\
\hline & $0.2195^{* * *}$ & $3.6371^{* * *}$ \\
\hline Number of observ. & $(0.0424)$ & $(0.7316)$ \\
Number of groups & 220 & 219 \\
AR(1) test & 22 & 22 \\
AR(2) test & 0.0094 & 0.0046 \\
\hline
\end{tabular}

Source: Authors

Notes: $\Delta$ - the first differentiation, *sign. at $10 \% ; * *$ sign. at $5 \% ; * * *$ sign. at $1 \%$.

The null hypothesis, regarding no correlation of second order first residual differences is not rejected at the significance level of $5 \%$. The autocorrelation between the residuals in the model is not present, while the previous period coefficients of the dependent variables are statistically significant and directly contribute to the increase of the dependent variables from the current period. From the model's point of view, testing results confirm the basic research expectations.

The results of the both research models show the strong significant negative influence of the non-performing assets (NPA_Ratio) on the analysed sustainable profitability indicators. Moreover, the research clearly shows the lack of significance of the total regulatory capital variable (TCap_Ratio), which is nevertheless expected, due to the forced exogenous regulatory influence, related to the current business operation. Finally, accumulated toxic loan portfolio during the period of global financial crisis, caused by the non-rationality in the chosen operating model of risk management before the crisis, as well as the changed prudent regulatory framework, forced the banking industry into the longrun revaluation of the entire credit assets (Figure 1).

Banks' cost to income ratio, presented as an efficiency ratio, has the same negative sign, i.e. an increase in the same has the statistically significant negative impact on the sustainable profitability of the banking industry as a whole. It is obvious that only leaving some individual markets, eliminating unprofitable departments, especially those focused on global capital markets with exotic products, as well as controlling various forms of bonuses and earnings of management structures prudentially, lead to better cost management and more rational use of banking resources. Although the average value of the efficiency ratio is still high (Table 3), it can be expected that the started processes of fintech rationalization and return to the more traditional banking activities will have a positive influence on sustainable profitability combined with a reduction in the overall riskiness of credit assets.

Most studies confirmed that banks that are more efficient tend to record lower cost, 


\section{Journal of Contemporary Management Issues}

lower cost to income ratio, and higher profitability (Huljak et al., 2019). The transformation of the bank business model, the costs of banking regulation and new technologies in banking products and services have contributed to the cost function optimization, in order to achieve business objectives. Therefore, the nonperforming loan ratio indicates the credit risk management efficiency with a direct impact on cost of risk volume. During the phase of implementation of the IFRS9, some banks recognized underestimated credit risk in loan portfolio what caused the increase of the volume of provision and ratio of non-performing assets (European Banking Authority, 2017).

Research models do not indicate the significant impact of the regulatory capital ratio on ROA regardless of the fact that capital ratios of banks have been a key determinant of profitability and have enabled survival during the period of the financial crisis. Banks with the higher capital to risk weight assets ratio during the financial crisis better absorbed the crisis effects and indicated more stable overall business performance indicators, including the bank solvency (Berger and Bouwman, 2013). In the post-crisis period, banks have adopted the new capital requirements, while the banking groups with the lower profitability indicators (e.g. Deutsche Bank, Commerzbank, Unicredit and Royal Bank of Scotland) have been asked to increase capital buffers close to the level of most efficient banks from the sample. That caused the non-significant effect of risk to weight assets to the total bank capital on bank profitability performance indicators, which is opposite to some authors' research (Maraghni, 2017). The second research model provided the same results. Volume of the non-performing loans and the cost to income ratio have the most significant negative influence on ROE, which is compliant with the research of some other financial systems
(Nursiana, 2017). Research results indicate the irrelevant capital structure (out of the regulatory required) and importance of the income sustainability in the long term profit performance measures.

There is no significant impact of the natural logarithm assets on dependent variables in the presented models. Due to the sample characteristics, all banks exploited the size effect, as the bank size variable did not impact bank profitability indicators.

\section{CONCLUSION}

In post-crisis period, the business performance of the EU banks has been supported by consolidation and growing of economy, regulatory framework implementation, strong bank lending growth, and significant improvements in asset quality and capital ratio (European Commission, 2019). This paper analysed bank specific variables in finding out the differences in profitability measures observed among the banks in the research sample. The model results are in line with the base research hypothesis. Banks with better credit risk and efficiency management show better performance, according to the profitability indicators. Among the EU systemically important banks, the level of regulatory capital ratio has the same tendency, due to the regulatory changes, without significant influence on profitability measures, as well as the volume of the assets among the banks, which exploited the size effect. As a policy recommendation for the regulatory authorities, it is suggested to encourage efforts in credit risk of loan portfolio control and develop infrastructure for assets restructuring through securitization processes.

To support banking sector profitability is one of the objectives of prudential 
activities, due to maintaining of bank activities and long term stability. Bank decisionmakers can be advised to monitor credit risk, as well as to improve cost efficiency with new technology opportunities in transformation of bank business model, as a presumption to achieve sustainable profitability objectives. In addition, the BCBS issued technical guidance for banking supervision, in order to facilitate usage of digital technologies. Finally, these developments can enhance financial inclusion for individuals and businesses, who have been excluded from the formal financial markets (Kern, 2019). The analysis of the bank specific and structural determinants of cost efficiency can be designated for future research, due to the increase of competition in banking services and products.

\section{REFERENCES}

1. Andries, A.M., Cocris, V. (2010). A Comparative Analyses of the Efficiency of Romanian Banks, Romanian Journal of Economic Forecasting, 13, 54-75.

2. Athanasoglou, P.P., Delis, M.D., Staikouras, C.K. (2006). Determinants of Bank Profitability in the South Eastern European Region, Bank of Greece, Working Paper No. 47.

3. Athanasoglou, P.P., Brissimis, S.N., Delis, M.D. (2008). Bank-specific, industry-specific and macroeconomic determinants of bank profitability. Journal of International Financial Markets, Institutions and Money, 18(2), 121-136.

4. Berger, A.N., Bouwman, C. (2013). How does capital affect bank performance during financial crises?, Journal of Financial Economics, 109(1), 146-176.

5. Bitar, M., Pukthuanthong, K., Walker, T. (2018). The effect of capital ratios on the risk, efficiency and profitability of banks: Evidence from OECD countries. Journal of International Financial Markets Institutions and Money, 53(C), 227-262.

6. Boucinha, M., Ribeiro, N., WeymanJones, T. (2013). An assessment of Portuguese banks' efficiency and productivity towards euro area participation, Journal of Productivity Analysis, 39(2), 177-190.

7. Burger, A. \& Moormann, J. (2008). Productivity in Banks: Myths and Truths of the Cost Income Ratio, Banks and Bank Systems, 3(4), 92-101.

8. Cameron, C.A., Trivedi, P.K. (2005). Microeconometrics: Methods and Applications, Cambridge University Press.

9. Casu, B., Girardone, C., Molyneux, P. (2004). Productivity change in banking: A comparison of parametric and non-parametric approaches, Journal of Banking and Finance, 28(10), 2521-2540.

10. Dietrich, A., Wanzenried, G. (2011). Determinants of bank profitability before and during the crisis: Evidence from Switzerland. Journal of International Financial Markets, Institutions and Money, 21(3), 307-327.

11. ECB (2017). Business Models of the Banks in the Euro Area, Working Paper, No. 2070, May, 2017.

12. Ercegovac, R., Buljan, Z. (2018). Prilagodba sistemski značajnih banaka Europske unije regulatornim kapitalnim zahtjevima: očekivani učinci i prijeteći rizici, Financije: teorija i suvremena pitanja. Osijek: Sveučilište Josipa Jurja Strossmayera - Ekonomski fakultet, 127-140.

13. European Banking Authority (2017). Results from the second EBA impact 


\section{Journal of Contemporary Management Issues}

assessment of IFRS 9, EBA Report, July.

14. European Commission (2019). European Financial Stability and Integration, Review 2019, May.

15. Goddard, J., Molyneux, P., Wilson, J., (2004). Dynamics of Growth and Profitability in Banking, Journal of Money, Credit and Banking, 36(3), 1069-1090.

16. Heffernan, S.A, Fu, X. (2010). Determinants of financial performance in Chinese banking, Applied Financial Economics, 20, 1585-1600.

17. Huljak, I., Reiner, M., Moccero, D. (2019). The cost efficiency and productivity growth of Euro area banks, Working Paper No. 2305, European Central Bank, August.

18. Jeitschko, T.D., Jeung, S.D. (2005). Incentives for risk-taking in banking A unified approach. Journal of Banking and Finance, 29 (3), 759-777.

19. Jumono, S., Achsani, N.A., Hakim D.B., Fidaus, M. (2016). The effect of loan market concentration on banking rentability: A study of Indonesian commercial banking, dynamics panel data regression approach. International Journal of Economics and Financial Issues, 6(1), 207-213.

20. Kern, A. (2019). Principles of Banking Regulation. Cambridge University Press, United Kingdom.

21. Klaassen, P., van Eeghen, I. (2015). Analyzing bank performance - linking RoE, RoA and RAROC: U.S. commercial banks 1992-2014, Journal of Financial Perspectives, 3(2), 103-111.

22. Klinac, I., Ercegovac, R. (2018). Banking System Adjustment to Regulatory Capital Requirements, Croatian Economic Survey, 20(2), 69-96.
23. Klinac, I., Peša, A., Bolfek, B. (2019). Influence of regulatory capital requirements on the self-financing capacity of a banking company, Business and Economic Horizons, 15(1), 70-89.

24. Košak, M., Čok, M. (2008). Ownership Structure and Profitability of the Banking Sector: The Evidence from the SEE region, Zbornik radova Ekonomskog fakulteta u Rijeci, 26(1), $93-122$.

25. Kundid, A., Škrabić, B., Ercegovac, R. (2008). Determinants of Bank Profitability in Croatia, Croatian Operational Research Review, 2(1), 168-182.

26. Mala, C.M.F. (2017). The prospect of dual unit banking system in Indonesian regional banking. Account and Financial Management Journal, 2(1), 592-599.

27. Maraghni, H. (2017). Bank Regulation, Capital Ratio Behaviour and Risk Taking in a Simultanious Approach, International Journal of Financial Research, 8(1), 43-64.

28. Molyneux, P., Thorton, J. (1992). Determinants of European Bank Profitability, Journal of Banking and Finance, 16, 1173-1178.

29. Nursiana, A. (2017). Effect of non-performing loans to profitability of banks in Indonesia. International, Journal of Applied Business and Economic Research, 15(10), 203-208.

30. Pasiouras, F., Kosmidou, K. (2007). Factors influencing the profitability of domestic and foreign commercial banks in the European Union. Research in International Business and Finance, 21(2), 222-237.

31. Petria, N., Capraru, B., Ihnatov, I. (2015). Determinants of Banks' Profitability: Evidence from EU 27 
Banking Systems. Procedia Economics and Finance, 20, 518-524.

32. Pivac, S., Aljinović Barać, Ž., Tadić, I. (2017). An analysis of human capital investments, profitability ratios and company features in the EU. Croatian Operational Research Review, 8(1), 167-180.

33. Raluca, A.R. (2020). Winners and losers from supervisory enforcement actions against banks, Journal of Corporate Finance, 60, February, 1-31.

34. Saeed, M.S., Zahid, N. (2016). The Impact of Credit Risk on Profitability of the Commercial Banks, Journal of Business \& Financial Affairs, 5(2), 1-7.

35. Short, B. (1979). The Relationship between Commercial Bank Profit Rates and Banking Concentration in Canada, Western Europe and Japan, Journal of Banking and Finance, 3, 209-2019.

36. Simanjuntak, R.H., Pangestuti, R.D. (2017). Enhancing banking performance by reducing risk: A preliminary study on the productive credit-based loan portfolio. International Journal of Applied Business and Economic Research, 15(15), 157-167.

37. Spierdijk, L., Shaffer, S., Considine, T. (2017). How do banks adjust to changing input prices? A dynamic analysis of US commercial banks before and after the crisis, Journal of Banking and Finance, 85, December, 1-14.

38. Staikouras, C., Wood, G. (2004). The Determinants of European Bank Profitability. International Business \& Economics Research Journal, 3(6), 57-68.

39. Sufian, F. (2012). Determinants of bank profitability in developing economies: Empirical evidence from the South Asian banking sectors. Contemporary South Asia, 20(3), 375-399.

40. Škrabić Perić, B. (2012). Utjecaj stranog vlasništva banke na njezin kreditni rizik u zemljama srednje i istočne Europe: dinamički panel modeli. (Unpublished doctoral dissertation). Faculty of Economics, University of Split.

41. Verbeek, M. (2004). A guide to modern econometrics (2nd ed.). West Sussex: John Wiley \& Sons Ltd.

42. Wooldridge, J. M. (2002). Econometric analysis of cross section and panel data. Cambridge, MA and London: The MIT Press. 


\section{SPECIFIČNE ODREDNICE PROFITABILNOSTI BANAKA U EUROPSKOJ UNIJI NAKON FINANCIJSKE KRIZE 2017. GODINE}

Sažetak. Temeljni cilj ovog rada je istražiti odrednice indikatora profitabilnosti banaka $u$ Europskoj Uniji. Standardni pokazatelji profitabilnosti banaka su povat na ukupnu imovinu banke (ROA) i povrat na ukupnu vlastitu imovinu banke (ROE). Istraživački model odrednica bankovne profitabilnosti razvijen je analizom sistemski značajnih banaka u Europskoj Uniji, listanih na tržištima kapitala, u periodu od 2017. do 2019. godine, korištenjem odgovarajuće tehnike analize panel podataka. Rezultati empirijskog istraživanja su u skladu s inicijalnim pretpostavkama: efikasnost banaka, mjerena odnosom troškova $i$ prihoda te odnosom nenaplativih kredita, ima značajan utjecaj na profitabilnost, kako na ROA, tako i na ROE. $U$ post-kriznom periodu, banke su orijentirane na efikasnost upravljanja troškovima, kako bi postigle svoje poslovne ciljeve. Dodatni značajni rezultati istraživanja odnose se na nepostojanje utjecaja veličine imovine te udjela regulatornog kapitala na indikatore profitabilnosti. Najznačajniji doprinos ovog rada odnosi se na definiranje uzorka, izbor varijabli i snagu predviđanja prezentiranog modela u objašnjavanju globalnih tendencija u bankarstvu.

Ključne riječi: profitabilnost banke, regulatorni zahtjevi, dinamički panel modeli, sistemski značajne banke, Europski bankarski sektor 